

\section{Methane production from insect, worm and mushroom waste streams and combinations}

Hellen Elissen ${ }^{1}$, Stefan $\mathrm{Hol}^{1}$ \& Rommie van der Weide ${ }^{1}$

1 Wageningen University \& Research

This study was carried out by the Wageningen Research Foundation (WR), Business Unit Field Crops and was commissioned and financed by the PPP Biobased valorisation of manure and digestate AF-17052b. This project is financially supported by the Dutch Topsector Agri \& Food. Within the Topsector, private industry, knowledge institutes and the government are working together on innovations for safe and healthy food for 9 billion people in a resilient world.

WR is part of Wageningen University \& Research, the collaboration of Wageningen University and Wageningen

Wageningen, December 2019

Report WPR-817 
Elissen, H. \& R. van der Weide, 2019. Methane production from insect, worm and mushroom waste streams and combinations. Wageningen Research, Report WPR-817. 22 pp.; 6 fig.; 4 tab.; 22 ref.

This report can be downloaded for free at https://doi.org/10.18174/515048

Summary: In literature, the synergistic effect of several substrates on feedstocks for anaerobic digestion/methane production is described for several substrates. Champost from mushroom production, vermicompost from worm composting/vermiculture and BSF (black soldier fly) larvae frass from insect production were therefore tested for this report for their synergistic effect. It was found that insect frass had a very high biogas/methane production as a single substrate. Addition of the frass led to biogas productions in mixtures with 'old' digestate higher than were expected based on the results of the single substrates. Champost resulted in some biogas production but from vermicompost hardly any biogas could be produced. Also, no synergistic or concentration effects could be noted from the latter two.

Keywords: biogas, methane potential, black soldier fly, frass, champost, mushroom waste, vermicompost

(c) 2019 Wageningen, Stichting Wageningen Research, Wageningen Plant Research, Business Unit Field Crops, P. O. Box 430, 8200 AK Lelystad, The Netherlands; T +31 320291 111; www.wur.eu/plantresearch

Chamber of Commerce no. 09098104 at Arnhem

VAT NL no. 8065.11.618.B01

Stichting Wageningen Research. All rights reserved. No part of this publication may be reproduced, stored in an automated database, or transmitted, in any form or by any means, whether electronically, mechanically, through photocopying, recording or otherwise, without the prior written consent of the Stichting Wageningen Research.

Stichting Wageningen Research is not liable for any adverse consequences resulting from the use of data from this publication.

Report WPR-817

Photo cover: Arnaud Duine 


\section{Contents}

$\begin{array}{ll}\text { Preface } & 5\end{array}$

$\begin{array}{ll}\text { Summary } & 7\end{array}$

1

$\begin{array}{ll}\text { Introduction } & 9\end{array}$

$\begin{array}{lll}1.1 & \text { Vermicompost } & 9\end{array}$

1.2 Insect frass 9

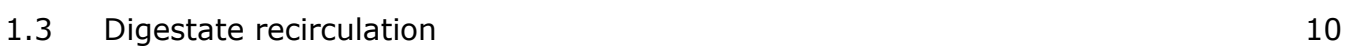

$\begin{array}{lll}1.4 & \text { Champost } & 10\end{array}$

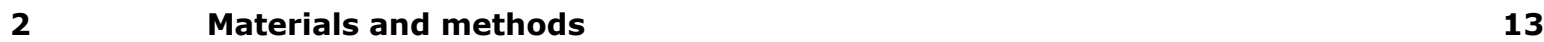

2.1 Input materials/additions $\quad 13$

$\begin{array}{lll}2.2 & \text { Anaerobic digestion tests } & 13\end{array}$

$\begin{array}{llr}3 & \text { Results } & 15\end{array}$

$\begin{array}{lll}3.1 & \text { Biogas production and quality } & 15\end{array}$

$\begin{array}{lll}3.2 & \text { Other parameters } & 17\end{array}$

4 Discussion and conclusion $r$

$\begin{array}{llr}5 & \text { Recommendations } & 21\end{array}$

$\begin{array}{ll}\text { References } & 23\end{array}$

Annex 1 pH values and substrate dosages at start and end of anaerobic digestion tests $(n=3)$ 



\section{Preface}

In the Netherlands, there are surpluses of manure and digestates/biogas slurries (digested manure and residual flows), which represent a negative value. At the same time, these residual flows contain valuable ingredients for the production of biomass (as raw material for food and feed products), for improving soil quality and for energy production. The number of feasible business cases in which the residual flow is upgraded has so far been limited. This is due both to the efficiency of the technologies used and the legislation and regulations related to the residual flows.

Recent information from research, scientific literature and companies provides new starting points for a biobased valorisation of manure/digestate streams and improving the efficiency of anaerobic digestion. The innovative aspect of our research is the cultivation of new types of biomass on the residual flows and the use of the conversion products to improve anaerobic digestion. This involves the use of separated manure and digestate products for the cultivation of mushrooms/fungi, worms, insects, specific bacteria and aquatic biomass. The resulting biomass can be further refined and marketed as food, feed and bio-based feedstock. There are also processed manure and digestate products that are valuable as fertilizer products for soil and plant growth, as substrate for improvement of anaerobic digestion or for export/use besides in agriculture. This gives a new interpretation to obligatory manure processing.

The aim of this project is to further explore and substantiate/test these ideas on lab and practical scale, leading to a proof of principles for new bio-based upgrading methods for manure and digestate that can be used in conjunction to better close cycles and/or sell outside regular agriculture.

Bottlenecks in legislation and regulations are explored and put on the agenda. Key figures are also calculated that are necessary for assessing sustainability (e.g. costs, environmental effects) and for supporting legislation (e.g. minerals, food safety).

The livestock sector gains insight into the possibilities of biobased valorisation and better marketing of their most important residual flows. For the SMEs involved, this research provides proof of principle for their technology and input in their business cases. The combined effects of the technologies provide new knowledge, methods and research directions for science. In a social context, the use and upgrading of manure and digestates in other ways also contributes to the transition to a circular bioeconomy with an efficient and sustainable agrifood sector.

More information:

- http://www.acrres.nl/en/projecten_acrres/biobased-valorization-of-manure-and-digestate/

- Rommie van der Weide: rommie.vanderweide@wur.nl, +31320291631

- Hellen Elissen: hellen.elissen@wur.nl, +31320291223






\section{Summary}

In literature, the synergistic effect of several substrates on feedstocks for anaerobic digestion/methane production is described for several substrates. Champost from mushroom production, vermicompost from worm composting/vermiculture and BSF (black soldier fly) larvae frass from insect production were therefore tested for this report for their synergistic effect. It was found that insect frass had a very high biogas/methane production as a single substrate. Addition of the frass led to biogas productions in mixtures with 'old' digestate higher than were expected based on the results of the single substrates. Champost resulted in some biogas production but from vermicompost hardly any biogas could be produced. Also, no synergistic or concentration effects could be noted from the latter two. 


\section{Introduction}

In general, methane production during anaerobic digestion is dependent on the (macro)composition of the substrate. As a general rule, simple carbohydrates (starch and sugars) are the most suitable for anaerobic digestion, followed by lipids and proteins (Groene Rekenkamer, 2015). Complex carbohydrates (fibrous crops) are difficult to digest and complex polymers (e.g. lignin in woody wastes) are not digestible at all. Methane production during anaerobic digestion of organic wastes can be enhanced in several ways. Gil et al (2019) for example describe the influence of the $C /[N+P]$ ratio on anaerobic digestion. They found (amongst other things) that when soluble and biodegradable carbon is added to the feedstock during anaerobic digestion, most of it was converted to biogas at a $\mathrm{C} /[\mathrm{NP}]$ ratio between 40 and 53 . Next to the influence of nutrient ratios, a synergistic effect by addition of residual streams from other production processes could have an influence according to some literature. Champost from mushroom production, vermicompost from worm composting/vermiculture and BSF (black soldier fly) larvae frass from insect production were therefore tested for this report for their synergistic effect. Possibly, the presence of different organisms (e.g. bacteria, fungi) or components (e.g. enzymes, micronutrients) from the additions can enhance biogas production by extra or faster breakdown of the digester feedstock(s), as is described in some of the literature below.

\section{$1.1 \quad$ Vermicompost}

Several authors state that the addition of vermicompost enhances the production of methane during anaerobic digestion. Chen et al (2010) concluded that co-digestion with vermicompost from cow manure improved the biodegradability of corn stalk, and the methane yield was improved by 4.4-58.6 $\%$. Co-digestion lead to higher $\mathrm{pH}$ values and VFA concentrations due to a positive synergistic effect between corn stalk and vermicompost and a high chitinase concentration in the vermicompost. This synergistic effect was speculated to be due to the supply of missing nutrients and the reduction/dilution of inhibitory materials in the feedstock by co-substrates. X-ray diffraction analyses showed that the destruction of crystalline cellulose was enhanced by addition of vermicompost. The highest methane yield of $259.4 \pm 13.9 \mathrm{~m}^{3} /$ ton DM added and the highest destruction rate of $29.4 \%$ were found for 40/60 vermicompost/corn stalk. Yang et al (2009) concluded that the addition of 0.9$8.33 \%$ vermicompost from cow manure (total solids based) lead to an increase in maximum specific methanogenic activity with a $45 \%$ increase relative to the control at the highest concentration. Also COD removal and buffering capacity of the system were improved. They ascribe the effects to several characteristics of the vermicompost: the porous granular shape and accompanying larger surface area, the content of microorganisms (bacteria, actinomycetes and fungi) and several enzymes (cellulase, amylase, protease, peroxidase, urease, phosphatase and dehydrogenase), the macronutrients (N, P, K) and micronutrients (Fe, Co, Mn, Cu etc). Wang et al (2017) studied the use of vermicompost from cow manure and biochar derived from it for its influence on anaerobic digestion. They found that both vermicompost and vermicompost biochar had a buffering capacity for shortchain VFAs, with the biochar having the largest capacity. Serrano et al (2016) studied the possibility that the addition of aquatic worm faeces can enhance biogas production from sewage sludge. They concluded that there was no clear direct (synergistic) effect on biogas production. However, this also seemed to depend on the type of feedstock applied, in this case high-loaded sewage sludge.

\subsection{Insect frass}

There is hardly quantitative info available on the anaerobic digestibility of BSF larvae frass or possible synergistic effects on anaerobic digestion of other substrates. It is usually only mentioned that the frass can be used for biogas production. Dortmans et al (2017) mention that preliminary results have 
shown that the expected biogas amounts from BSF frass compare to that produced from cow manure. Mertenat et al (2019) mention anaerobic digestion of BSF frass as a solution for both waste management and energy generation. Composting of the frass leads to higher greenhouse gas emissions. Lalander et al. (2018) found a biogas production from BSF frass from food waste of 576 $\mathrm{Nm}^{3} /$ ton OM with a methane percentage of $61 \%$ as compared to $695 \mathrm{Nm}^{3} /$ ton OM and $64 \%$ for the original food waste. BSF larvae treatment thus decreased the biomethane potential of food waste by around $20 \%$. They show a scenario for combining BSF production with anaerobic digestion:

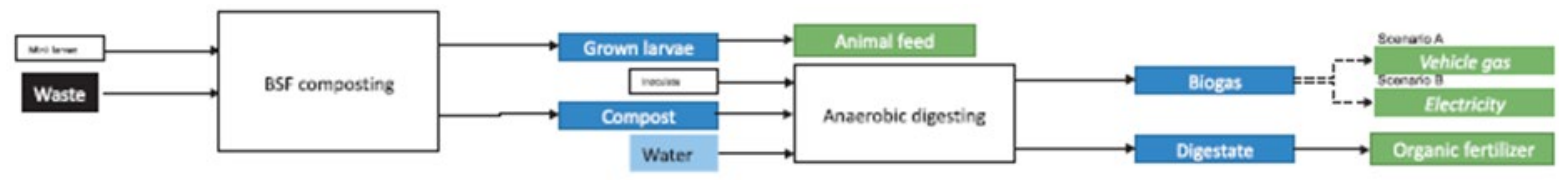

Figure 1 Treatment scenario for combining BSF and biogas production on waste (from Lalander et al, 2018).

\subsection{Digestate recirculation}

ReciDigest (2018) was a project that focused on increasing the biogas potential of digester feedstocks (i.e. cow manure) by applying innovative disintegration and recirculation (of the digestate produced from cow manure) techniques. Ultrasonic technology or oxidation techniques (ozone and hydrogen peroxide) were tested, which should result in the conversion of the remaining organic fraction of the digestate into anaerobically biodegradable molecules. Subsequently the digestate was returned to the digester as secondary feedstock. Removal of ammonia was tested to prevent inhibition of the digestion process. The results showed that the oxidation techniques had no effect and that ultrasonic techniques were too costly to compensate for the extra biogas production. Also, ammonia stripping required a large part of the biogas production and $10 \%$ digestate recirculation was not feasible.

\subsection{Champost}

Biogas production from champost has been studied in several researches. It has to be mentioned however that substrates for mushroom production vary according to the species of mushroom produced, but substrates for insect and worm production are also variable. Fleming et al (2006) tested the mesophilic anaerobic digestion of spent (regular) mushroom substrate (champost) and found that the methane yield from the steady state system averaged $53 \mathrm{~m}^{3} \mathrm{CH}_{4} /$ ton OM. The biogas had a methane content of around $50 \%$. They concluded that the yield is considerably less than that from livestock manure (288-562 $\mathrm{m}^{3} \mathrm{CH}_{4}$ /ton OM, depending on manure type). 46-62 \% of the champost mass was broken down during anaerobic digestion. Xiao et al (2018) studied thermophilic (usually at around $53-55^{\circ} \mathrm{C}$ ) anaerobic digestion of champost from $P$. eryngii. They found a cumulative methane yield of $178 \mathrm{~m}^{3} /$ ton OM. The methane concentration was $54 \%$. They also found cellulose and hemicellulose degradation of 48 and $55 \%$ respectively, which was previously found to be below 40 and $20 \%$ respectively in a previous study employing mesophilic digestion. They analysed the bacterial community present during the digestion process and found it to be quite different from that in anaerobic digestion of other feedstocks. Uslu et al (2018) mention that the anaerobic digestion of champost is quite difficult due to its high ash and salt contents. Sethumadhavan and Selvan (2018) co-digested waste paper with spent mushroom substrate (from production of $P$. florida) as powder and found a methane yield of $168 \mathrm{~m}^{3} \mathrm{CH}_{4}$ /ton OM. When spent mushroom substrate - waste paper as briquette was used (made from the powder a higher methane yield of $250 \mathrm{~m}^{3} \mathrm{CH}_{4} /$ ton OM was observed. According to the authors this was due to a better accessibility of the microorganisms to the feedstock as a result of the mechanical pre-treatment. Lin et al (2014) found that champost from mainly sawdust was highly degradable in solid state anaerobic digestion and that the formation of VFAs with a concomitant $\mathrm{pH}$ drop inhibited methane formation. When co-digested with yard trimmings the methane yield was $269 \mathrm{~m}^{3} \mathrm{CH}_{4}$ /ton OM. Liquid digestion may be a better option. Oei and Albert (2008) stated that the energy generation from champost is too low (lower than that of manure) to justify investments in an anaerobic digester due to its lignin content ( $\sim 50 \%)$. Pre-treatment may be a 
solution. Acid hydrolysis may lead to better results than alkalic hydrolysis, since the latter requires large amounts of hydrolysis agent. Zhou et al (2014) found that VFA production from waste activated sludge could be improved due to a synergistic effect by 'co-conditioning' with carbohydrates in spent mushroom waste (from $A$. bisporus production) combined with alkaline, alkaline-thermal and ultrasonic pre-treatments. The treatment resulted in higher concentrations than those resulting from sole pre-treatment or co-digestion with carbon-rich substrates. Protein-like, humic-acid-like and fulvicacid-like substances were produced and higher protein degradation was found. Alkaline-thermal was the most successful treatment combined with mushroom waste. 


\section{Materials and methods}

\subsection{Input materials/additions}

Four substrates were tested in lab-scale mesophilic anaerobic digestion tests.

1. Champost: produced from straw, chicken and horse manure and conditioning agent gypsum, obtained from CNC (Milsbeek, the Netherlands). The champost had not been steamed/hygienised.

2. Insect frass: produced by $H$. illucens larvae on food industry residuals, obtained from Bestico (Berkel en Rodenrijs, the Netherlands). Hygienised at $60^{\circ} \mathrm{C}$ overnight.

3. Vermicompost: produced by E. fetida on ACRRES solid fraction of digestate, obtained from Lumbriculus (Oostwold, the Netherlands)

4. Digestate ('old', non-separated, obtained from WUR-ACRRES, Lelystad, the Netherlands) Table 1 shows the basic composition of the input materials.

Table 1 Composition of pure input materials/additions. $D=$ digestate, $C=$ champost, $I=$ insect frass, $V C=$ vermicompost. Approximate results were taken from previous samples.

\begin{tabular}{lllllll}
$\begin{array}{l}\text { Test } \\
\text { substrate }\end{array}$ & $\begin{array}{l}\text { DM } \\
\% \text { ww }\end{array}$ & $\begin{array}{l}\text { OM DM } \\
\%\end{array}$ & $\begin{array}{l}\text { Ntotal } \\
\% \text { DM } \\
\text { (approximate) }\end{array}$ & $\begin{array}{l}\text { P DM } \\
\text { (approximate) }\end{array}$ & $\begin{array}{l}\text { EC } \\
\text { ms/cm 25 } \\
\text { (approximate) }\end{array}$ & $\begin{array}{l}\text { PH } \\
\text { (approximate) }\end{array}$ \\
\hline C & 9 & 65 & 5.0 & 0.7 & 12.4 & 5.7 \\
\hline I & 37 & 61 & 2.2 & 0.5 & 1.7 & 7.1 \\
\hline VC & 63 & 90 & 3.7 & 1.1 & 8.7 & 6.4 \\
\hline
\end{tabular}

\subsection{Anaerobic digestion tests}

The anaerobic digestion tests were performed by Opure (Ede, the Netherlands). Test substrates were added in triplicate tests according to Table 2.

Table 2 Test substrates in anaerobic digestion tests $(n=3)$ and test durations. $D=$ digestate, $C=$ champost, $I=$ insect frass, $V C=$ vermicompost. $100=100 \%, 90 / 10=90 \% / 10 \%, 70 / 30=70 \% /$ $30 \%$.

\begin{tabular}{lc} 
Test substrate & Test duration (days) \\
D 100 & 67 \\
\hline C 100 & 60 \\
\hline I 100 & 60 \\
\hline VC 100 & 67 \\
\hline D/C $90 / 10$ & 95 \\
\hline D/C 70/30 & 95 \\
\hline D/I 90/10 & 65 \\
\hline D/I 70/30 & 95 \\
\hline D/VC $90 / 10$ & 65 \\
\hline D/VC 70/30 & 65 \\
\hline
\end{tabular}

Pre-treated digestates were used as seed material for the tests. The structure had to be as homogeneous as possible for an equal distribution over the test vessels, with as low biogas formation and as many different bacteria as possible. This was achieved by using three different digestates from low-loaded systems, which were pre-processed (e.g. coarse parts were sieved out). As mentioned, the seed digestates should produce as little gas as possible, otherwise the measurement would be inaccurate (biogas production was measured as the difference between vessels with only seed digestates and vessels with seed digestates plus added test substrates, both in triplicate). 200 grams of seed digestates and 1.1-48.6 grams of single and mixed test substrate(s) (Appendix I) were added to $1.2 \mathrm{~L}$ vessels. The dosages of the test substrates were based on predetermined loads to obtain the right amount of biogas production and were based on organic matter content of the substrates. DM and OM were determined in all the substrates prior to the tests. COD could not be determined due to the presence of large particles in the samples. $\mathrm{pH}$ values were determined at the start and end of the 
tests in each vessel for the total mixtures. In each vessel a stirrer was added and they were flushed with nitrogen and closed. The vessels were put in an incubator at $35^{\circ} \mathrm{C}$ and stirred only once a week briefly). Biogas production was determined by measuring gas pressure and analysing gas composition, after which results were converted to standard $\mathrm{m}^{3}\left(\mathrm{~nm}^{3}\right)$ biogas (= differences in yield between reference and substrate vessels). Tests were terminated when net biogas formation was zero. 


\section{Results}

\subsection{Biogas production and quality}

Even though test durations varied (Table 2, 60-95 days) final biogas productions were not significantly different from those after 60 days (the duration of the shortest test) with all substrates, therefore it was decided to use the final data for results processing. The biogas production in time in the single and mixed substrates per ton are shown in Figures 2 and 3 respectively.

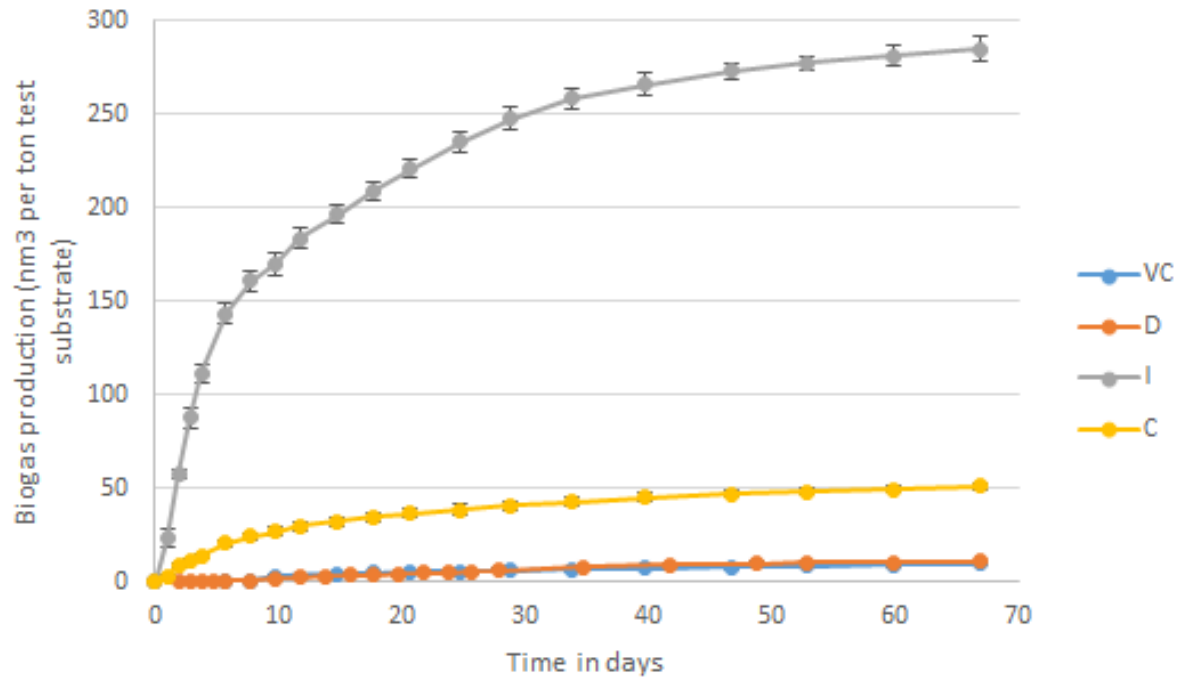

Figure 2 Biogas production of the single substrates $(n=3) . D=$ digestate, $C=$ champost, $I=$ insect frass, $V C=$ vermicompost.

Clearly, insect frass had the highest biogas production per ton, followed by champost with a more than fivefold lower production and vermicompost and digestate with both a more than tenfold lower production.

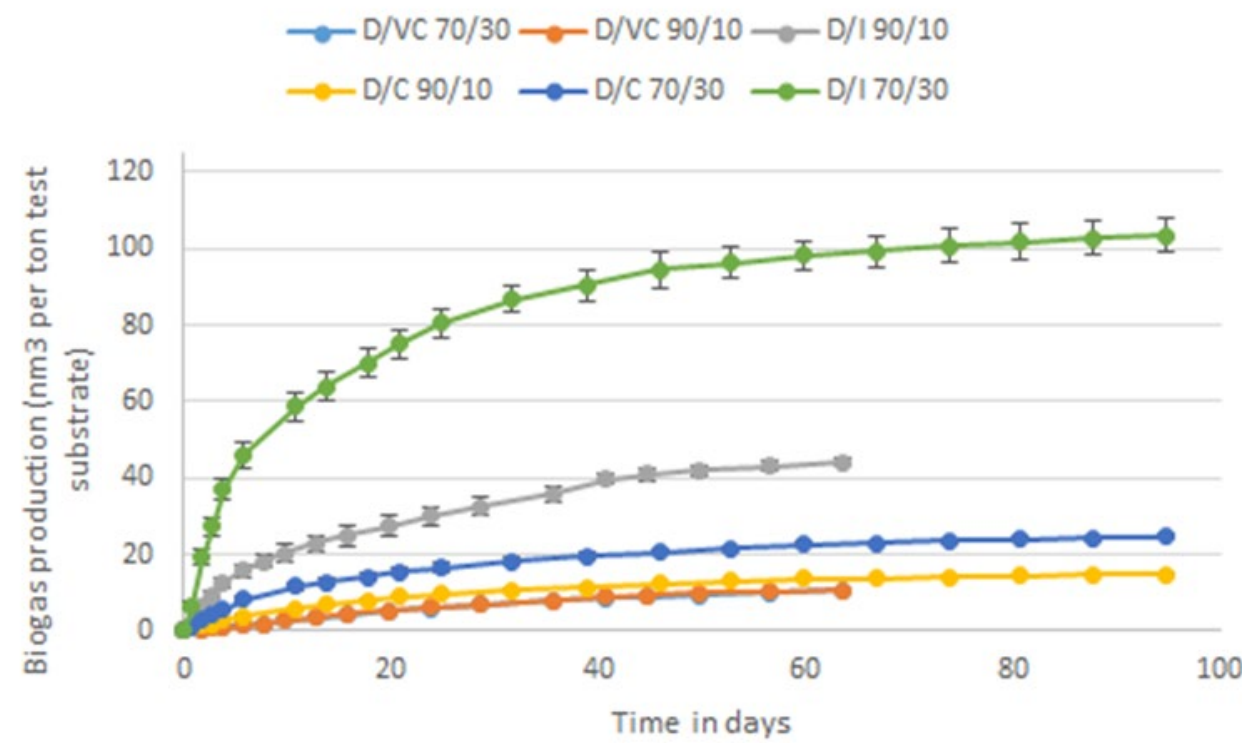

Figure 3 Biogas production of the mixed substrates $(n=3) . D=$ digestate, $C$ = champost, $I=$ insect frass, $V C=$ vermicompost. $100=100 \%, 90 / 10=90 \% / 10 \%, 70 / 30=70 \% / 30 \%$. 
Figure 3 shows that combinations with insect frass and champost lead to the highest biogas production, with increasing concentrations of additions leading to higher productions. For vermicompost this effect is almost absent. Table 3 shows the final values of biogas and methane production in the single and mixed substrates based on total product, and the biogas quality, all compared to calculated values based on the results of the single substrates.

Table 3 Measured biogas and methane productions on total product basis and biogas qualities compared to calculated values based on single substrates.

\begin{tabular}{|c|c|c|c|c|c|c|}
\hline Addition & $\begin{array}{l}\text { Biogas } \\
\text { ( } \mathrm{nm}^{3} / \text { ton prod.) }\end{array}$ & Calc & $\begin{array}{l}\mathrm{CH}_{4} \\
\left(\mathrm{~nm}^{3} / \text { ton prod.) }\right.\end{array}$ & Calc & $\begin{array}{l}\text { Biogas quality } \\
\% \mathrm{CH}_{4}\end{array}$ & Calc \\
\hline D 100 & 11 & & 7 & & 60 & \\
\hline C 100 & 51 & & 25 & & 48 & \\
\hline I 100 & 285 & & 166 & & 58 & \\
\hline VC 100 & 10 & & 4 & & 38 & \\
\hline D/C 90/10 & 15 & 15 & 8 & 8 & 53 & 58 \\
\hline $\mathrm{D} / \mathrm{C} 70 / 30$ & 25 & 23 & 12 & 12 & 50 & 56 \\
\hline D/I 90/10 & 44 & 38 & 26 & 22 & 58 & 59 \\
\hline D/I 70/30 & 104 & 93 & 60 & 54 & 58 & 59 \\
\hline D/VC $90 / 10$ & 11 & 11 & 6 & 6 & 55 & 57 \\
\hline D/VC 70/30 & 11 & 11 & 6 & 6 & 54 & 53 \\
\hline
\end{tabular}

Biogas quality ranged from 38-60\% and was highest for digestate, followed by insect frass, champost and vermicompost. In the mixtures biogas quality ranged between 50-58 \%. Biogas production was much more variable (as can also be seen in Figure 2) ranging from 10-285 $\mathrm{nm}^{3}$ biogas/ton product and was by far the highest for insect frass, followed by champost, digestate and vermicompost. From the single substrates values were calculated for the mixtures. Clearly biogas and methane production were higher for the combinations with insect frass than the calculated values, while the biogas quality was the same. Biogas quality for champost combinations was lower than expected. Calculated values for vermicompost combinations were very comparable to the measured data. As only combinations with insect frass resulted in higher productions than predicted components in the frass either stimulated higher productions from the other substrates (however, gas production from the other substrates, either single or mixed, was always quite low in comparison to that from the frass, either single or mixed) or the mixing with other substrates resulted in higher productions from the frass. Final biogas and methane productions were plotted on dry matter (Figure 4) and organic matter basis (Figure 5) and compared to calculated values for the mixtures.

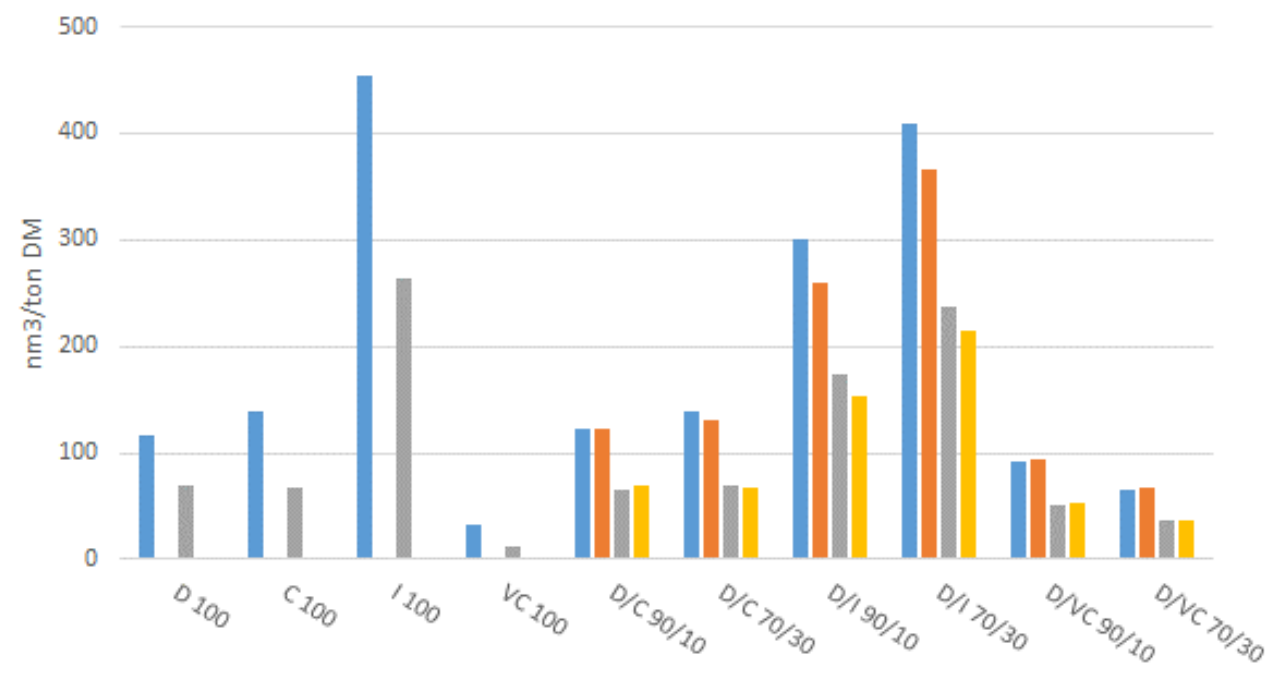

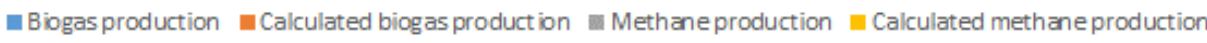

Figure 4 Production of biogas and methane per ton DM compared to calculated data. 


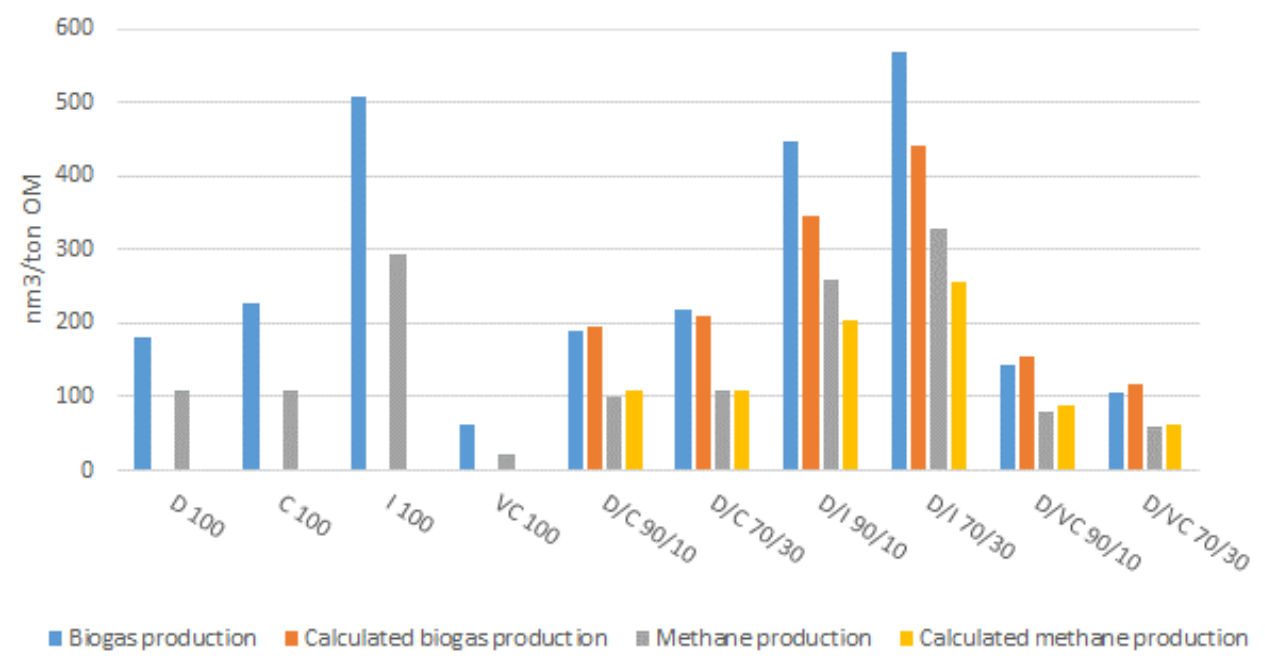

Figure $5 \quad$ Production of biogas and methane per ton OM compared to calculated data.

Also in these figures it can be seen that the highest biogas and methane production was found for insect frass, followed by champost/digestate and finally vermicompost. For champost combinations there was hardly an effect of concentration and calculated values for the mixtures were very comparable to measured values. For vermicompost combinations there also was hardly an effect of concentration and calculated values were even slightly higher than measured values. Finally, calculated biogas and methane productions for insect frass combinations were both lower on DM and OM basis.

\subsection{Other parameters}

In addition to biogas production also the organic matter breakdown in the single and mixed substrates as well as the net residual/non-digestible/non-fermentable material was calculated (Figure 6).

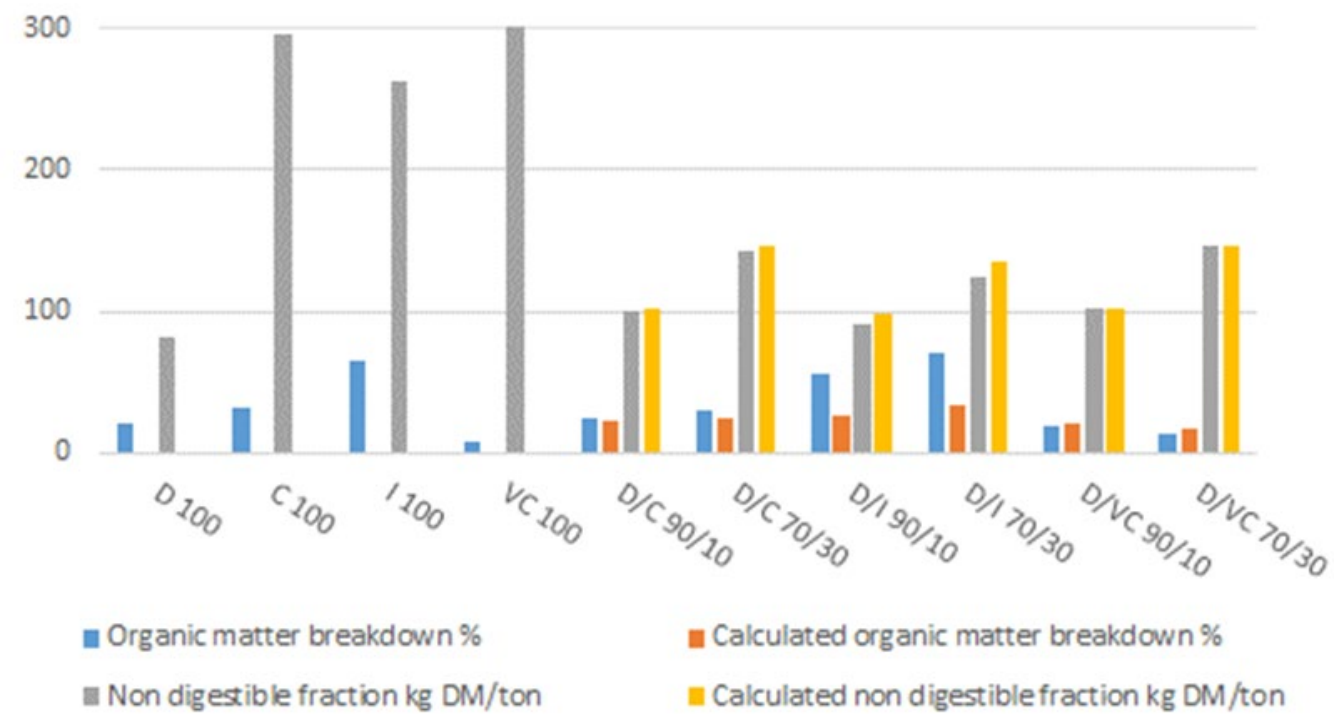

Figure 6 Organic matter breakdown (\%) and net non-digestible fraction of single and mixed substrates compared to calculated data.

As expected from the biogas data the highest organic matter breakdown was found for the insect frass, followed by champost, digestate and vermicompost. The non-digestible fraction was found to be in the same range for champost, insect frass and vermicompost (around $300 \mathrm{~g} \mathrm{DM} / \mathrm{kg}$ material), while that of digestate was less than $100 \mathrm{~g} \mathrm{DM} / \mathrm{kg}$ material. Since the highest initial OM percentage was found for insect frass (Table 1), most breakdown took place in this substrate. 


\section{Discussion and conclusion}

Table 4 shows biogas productions from several reference substrates.

Table 4 Measured biogas and methane productions on total product basis and biogas qualities compared to calculated values based on single substrates.

\begin{tabular}{|c|c|c|c|c|c|}
\hline Substrate & DM $\%$ & $\begin{array}{l}\text { Biogas } \\
\text { quality ( } \% \\
\left.\mathrm{CH}_{4}\right)\end{array}$ & $\begin{array}{l}\text { Biogas per } \\
\text { ton product }\end{array}$ & $\begin{array}{l}\text { Biogas per } \\
\text { ton DM }\end{array}$ & Reference \\
\hline Sewage sludge & 5 & 65 & 15 & 300 & SGC (2012) \\
\hline Fish waste & 42 & 71 & 537 & 1279 & SGC (2012) \\
\hline Straw & 78 & 70 & 207 & 265 & SGC (2012) \\
\hline Food waste & 33 & 63 & 204 & 618 & SGC (2012) \\
\hline Cattle slurry & 9 & 65 & 22 & 244 & SGC (2012) \\
\hline Potato haulm & 15 & 56 & 68 & 453 & SGC (2012) \\
\hline Slaughter waste & 16 & 63 & 92 & 575 & SGC (2012) \\
\hline Pig slurry & 8 & 65 & 26 & 325 & SGC (2012) \\
\hline Cow manure & & & 56 & & Biogas-E (2017) \\
\hline Pig manure & & & 55 & & Biogas-E (2017) \\
\hline Poultry manure & & & 48 & & Biogas-E (2017) \\
\hline Aerobic sludge & & & 13 & & Biogas-E (2017) \\
\hline Grass silage & & & 172 & & Biogas-E (2017) \\
\hline Cow manure & 8 & & 20 & 250 & Dijk, van and Durksz (2014) \\
\hline Corn silage & 33 & & 200 & 600 & Dijk, van and Durksz (2014) \\
\hline Insect frass & 63 & 58 & 285 & 454 & This report \\
\hline Vermicompost & 32 & 38 & 10 & 32 & This report \\
\hline Champost & 37 & 48 & 51 & 139 & This report \\
\hline Digestate 'old' & 9 & 60 & 11 & 117 & This report \\
\hline
\end{tabular}

When comparing the test substrates to other substrates for anaerobic digestion vermicompost and champost resulted in the lowest biogas quality. On product basis (which may not always be a fair comparison, due to highly variable DM percentages), vermicompost and digestate are substrates with the lowest biogas production, champost is in the middle range with manures, and insect frass is in the highest range with for example food waste. Based on dry matter, vermicompost had a very low biogas production, followed by low productions of champost and digestate. Insect frass was comparable to potato haulm and slaughter waste. For insect frass only produced by BSF larvae on food waste a biogas production of $576 \mathrm{Nm}^{3}$ /ton OM was found by Lalander et al (2018), which compares well to the $506 \mathrm{Nm}^{3}$ /ton OM we found (Figure 5). Bulak et al (2020) found biogas production rates for the frass of BSF larvae raised on carrot/beetroot waste of on average 351 and $412 \mathrm{Nm}^{3}$ biogas/ton DM and OM respectively and 177 and $208 \mathrm{Nm}^{3}$ methane/ton DM and OM respectively with an average methane content of $50 \%$. These numbers are comparable to our data and also to those of other insect species. In addition, from our data it seems that insect frass addition results in extra biogas production from regular substrates. Data for biogas production from champost only, range from $106-178 \mathrm{~m}^{3} /$ ton OM (Fleming et al, 2006; Xiao et al, 2018), which is a bit lower but in the same range as we found for champost (Figure 5). Also biogas quality was comparable to literature data, both for insect frass and champost. For vermicompost only, no data could be found. The low biogas production we found for vermicompost could be expected since it was produced on digestate from the ACRRES digester (on cow manure and natural grass), and thus had been successively 'digested' in cow, digester and worms. No synergistic effects, as were found in some researches described in literature were found for champost or vermicompost, which could be due to the input materials with low biological activity (e.g. digestate from $50 \%$ cow manure) or absence/too low concentrations of enzymes/micro-organisms for an effect to be noticeable. 


\section{Recommendations}

Based on the results insect frass seems a suitable substrate for anaerobic digestion, preferably to be applied with as little pre-treatment steps (e.g. drying to the current DM percentage) as possible. Also the seemingly synergistic effects (higher biogas production) of mixing insect frass with other substrates is worth further investigating: is it due to components in the frass or components in the other substrates? Vermicompost from fresher substrates (i.e. food waste, garden/vegetable/fruit waste) most likely has a higher potential for biogas production than the vermicompost used for this report. Champost with some basic pre-treatment (acidification? removal of salts by flushing?) may lead to better biogas production and already showed quite an acceptable production in these tests. For a synergistic effect to be noticeable in less active substrates such as vermicompost/champost higher concentrations in relation to the seed digestates could be an option in the test setup, since in the current setup they never exceeded a ratio of $2.4 / 100$. 


\section{References}

Biogas-E, 2017. Welke biomassastromen komen in aanmerking voor biogasproductie? https://www.biogas-e.be/kenniseninnovatie/inputstromen 24 augustus 2017

Bulak, P., K. Proc, M. Pawłowska, A. Kasprzycka, W. Berus and A. Bieganowski, 2020. Biogas generation from insects breeding post production wastes. Journal of Cleaner Production 244: 118777 Chen, G. Z. Zheng, S. Yang, C. Fang, X. Zou and Y. I. Luo, 2010. Experimental co-digestion of corn stalk and vermicompost to improve biogas production. Waste management 30 (10):1834-40 Dijk, W. van and D. Durksz, 2014. Energie uit bloembolresten. Bloembollenvisie 18 april 2014, p. 26 Dortmans B.M.A., Diener S., Verstappen B.M. and Zurbrügg C., 2017. Black Soldier Fly Biowaste Processing - A Step-by-Step Guide. Eawag: Swiss Federal Institute of Aquatic Science and Technology, Dübendorf, Switzerland. 100 pp.

Fleming, R., M. MacAlpine and S. English, 2006. Feasibility of Using Anaerobic Digestion and Composting to Recover Additional Value from Spent Mushroom Substrate. 50 pp.

Gil, A., J. A. Siles, A. Serrano, A. F. Chica and M. A. Martın, 2019. Effect of variation in the C/[N+P] ratio on anaerobic digestion. Environmental Progress \& Sustainable Energy 38 (1): 228-236 Groene Rekenkamer, 2015. De mestvergister. 29 december 2015.

https://www.groenerekenkamer.nl/5200/de-mestvergister/.

Lalander, C. H., A. Nordberg and B. Vinnerås, 2018. A comparison in product-value potential in four treatment strategies for food waste and faeces - assessing composting, fly larvae composting and anaerobic digestion. GCB Bioenergy 10: 84-91

Lin, Y., X. Ge and Y. Li, 2014. Solid-state anaerobic co-digestion of spent mushroom substrate with yard trimmings and wheat straw for biogas production. Bioresour Technol. 169: 468-474

Mertenat, A., S. Diener and Christian Zurbrügg, 2019. Black Soldier Fly biowaste treatment -

Assessment of global warming potential. Waste Management 84: 173-181

Oei, P. and G. Albert, 2008. Alternatieve toepassingen voor champost. Analyse van champost en dekaarde. Alternatieve verwerking van dekaarde. Toepassingen voor champost. Productschap Tuinbouw. 35 pp.

ReciDigest, 2018. https://www.biorefine.eu/projects/recidigest

Serrano, A., T. L. G. Hendrickx, H. J. H. Elissen, B. Laarhoven, C. J. N. Buisman and H. Temmink, 2016. Can aquatic worms enhance methane production from waste activated sludge? Bioresour Technol. 211: 51-7

Sethumadhavan, P. and V. Arul Mozhi Selvan, 2018. Effect of spent mushroom substrate and waste paper briquette on methane production from anaerobic digestion. Journal of Environmental Biology 39: $269-276$

SGC, 2012. Swedish Gas Technology Centre. Basic Data on Biogas. 29 pp.

Uslu, A., J. Daey Ouwens and M. Boots, 2018. CONCEPTADVIES SDE+ 2019. Vergisting. Notitie. PBLpublicatienummer: 3275. 23 pp.

Wang, D., J. Ai, F. Shen, G. Yang, Y. Zhang, S. Deng, J. Zhang, Y. Zeng and C. Song, 2017. Improving anaerobic digestion of easy-acidification substrates by promoting buffering capacity using biochar derived from vermicompost. Bioresource Technology 227: 286-296

Xiao, Z., M. Lin, J. Fan, Y. Chen, C. Zhao and B. Liu, 2018. Anaerobic digestion of spent mushroom substrate under thermophilic conditions: performance and microbial community analysis. Appl Microbiol Biotechnol 102: 499-507

Yang, S., J. Li, Z. Zheng, Y. Zhang, B. Zhang, 2009. Vermicompost as an accelerator of methane production. International Journal of Environmental Engineering 1(1): 52 - 63

Zhang, B., S. Yang and Y. Zhang, 2007. Enhancement of methane production by using vermicompost as additive. ASABE Annual International Meeting Sponsored by ASABE Minneapolis Convention Center Minneapolis, Minnesota 17 - 20 June 2007. 10 pp.

Zhou, A., J. Du, C. Varrone, Y. Wang, A. Wang, and W. Liu, 2014. VFAs bioproduction from waste activated sludge by coupling pretreatments with Agaricus bisporus substrate conditioning. Process Biochemistry 49: 283-289 


\section{Annex $1 \quad \mathrm{pH}$ values and substrate dosages at start and end of anaerobic digestion tests $(n=3)$}

\begin{tabular}{lcccccc} 
& pH start & \multicolumn{1}{c}{$\mathrm{pH}$ end } \\
\hline Test substrates & $\mathbf{1}$ & $\mathbf{2}$ & $\mathbf{3}$ & $\mathbf{1}$ & $\mathbf{2}$ & $\mathbf{3}$ \\
\hline D 100 & 7.76 & 7.76 & 7.76 & 7.61 & 7.61 & 7.59 \\
\hline C 100 & 7.72 & 7.72 & 7.72 & 7.51 & 7.52 & 7.52 \\
\hline I 100 & 7.74 & 7.74 & 7.74 & 7.48 & 7.50 & 7.48 \\
\hline VC 100 & 7.72 & 7.72 & 7.72 & 7.66 & 7.66 & 7.65 \\
\hline D/C 90/10 & 7.78 & 7.78 & 7.78 & 7.50 & 7.50 & 7.49 \\
\hline D/C 70/30 & 7.74 & 7.74 & 7.74 & 7.55 & 7.56 & 7.55 \\
\hline D/I 90/10 & 7.67 & 7.67 & 7.67 & 7.50 & 7.48 & 7.49 \\
\hline D/I 70/30 & 7.71 & 7.71 & 7.71 & 7.58 & 7.58 & 7.58 \\
\hline D/VC 90/10 & 7.72 & 7.72 & 7.72 & 7.52 & 7.51 & 7.51 \\
\hline D/VC 70/30 & 7.67 & 7.67 & 7.67 & 7.60 & 7.60 & 7.59 \\
\hline
\end{tabular}

\begin{tabular}{lcccc} 
& & 1 & 2 & 3 \\
Test substrates & & $\mathbf{g}$ & $\mathbf{g}$ & $\mathbf{g}$ \\
\hline D 100 & & 16.41 & 16.42 & 16.41 \\
\hline C 100 & & 3.58 & 3.58 & 3.58 \\
\hline I 100 & & 1.07 & 1.07 & 1.07 \\
\hline VC 100 & & 4.81 & 4.81 & 4.81 \\
\hline D/C 90/10 & D & 32.04 & 32.04 & 32.04 \\
\hline & C & 3.56 & 3.56 & 3.56 \\
\hline & Total & 35.60 & 35.60 & 35.60 \\
\hline D/C 70/30 & D & 8.31 & 8.31 & 8.31 \\
\hline & C & 3.56 & 3.56 & 3.56 \\
\hline & Total & 11.87 & 11.87 & 11.87 \\
\hline D/I 90/10 & D & 9.63 & 9.63 & 9.63 \\
\hline & I & 1.07 & 1.07 & 1.07 \\
\hline & Total & 10.70 & 10.70 & 10.70 \\
\hline D/I 70/30 & D & 2.50 & 2.50 & 2.50 \\
\hline & I & 1.07 & 1.07 & 1.07 \\
\hline & Total & 3.57 & 3.57 & 3.57 \\
\hline D/VC 90/10 & D & 43.76 & 43.76 & 43.76 \\
\hline & VC & 4.86 & 4.86 & 4.86 \\
\hline & Total & 48.62 & 48.62 & 48.62 \\
\hline D/VC 70/30 & D & 11.34 & 11.34 & 11.34 \\
\hline & VC & 4.86 & 4.86 & 4.86 \\
\hline & Total & 16.20 & 16.20 & 16.20 \\
\hline & & & & \\
\hline & & & & \\
& & &
\end{tabular}





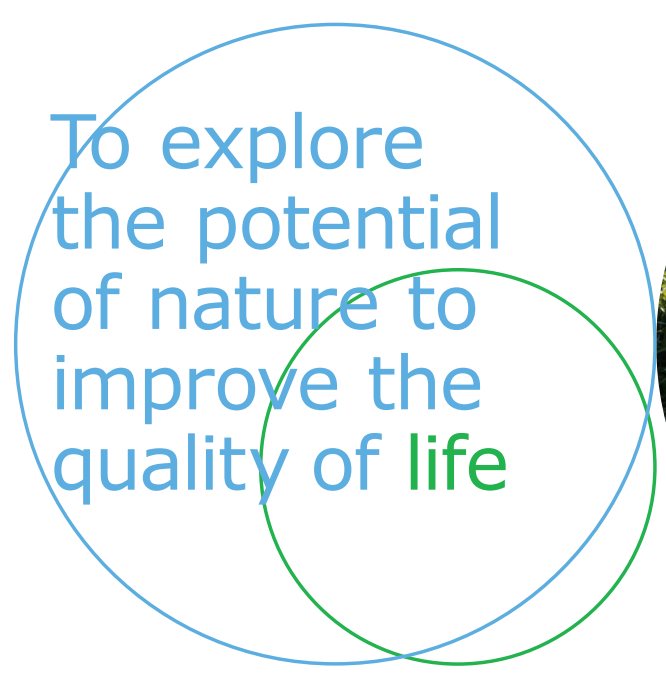

Corresponding address for this report: Wageningen University \& Research | Field Crops P.O. Box 430 8200 AK Lelystad The Netherlands T +31 (0)320 291111 www.wur.eu/fieldcrops

Rapport WPR-817

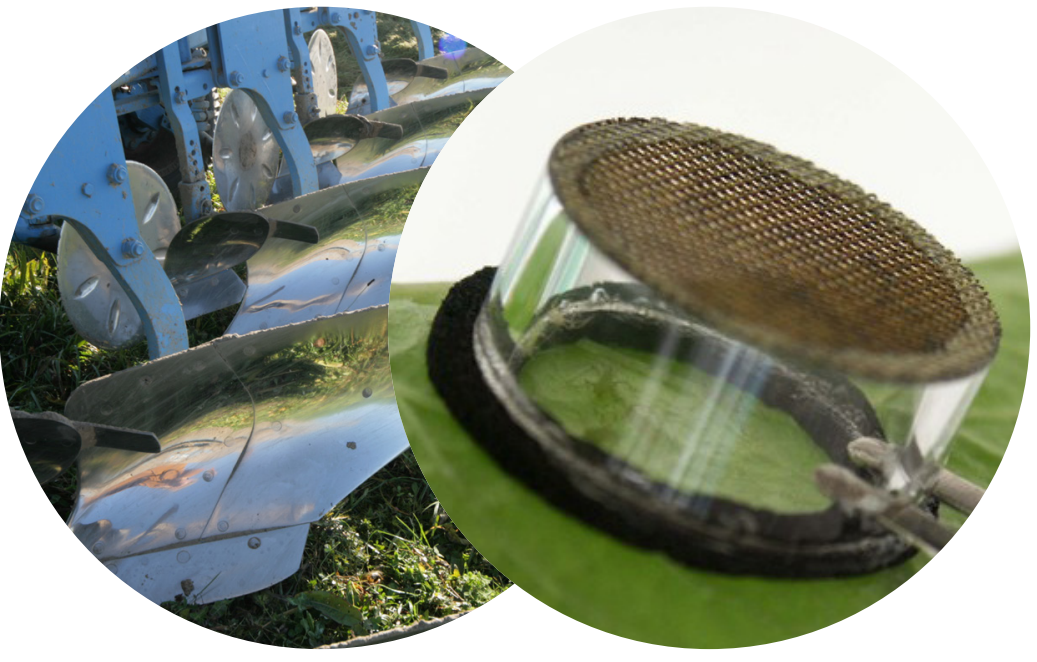

The mission of Wageningen University and Research is "To explore the potential of nature to improve the quality of life". Under the banner Wageningen University \& Research, Wageningen University and the specialised research institutes of the Wageningen Research Foundation have joined forces in contributing to finding solutions to important questions in the domain of healthy food and living environment. With its roughly 30 branches, 5,000 employees and 10,000 students, Wageningen University \& Research is one of the leading organisations in its domain. The unique Wageningen approach lies in its integrated approach to issues and the collaboration between different disciplines. 